Tropical Journal of Pharmaceutical Research December 2013; 12 (6): 897-903

ISSN: $1596-5996$ (print); 1596-9827 (electronic) (C) Pharmacotherapy Group, Faculty of Pharmacy, University of Benin, Benin City, 300001 Nigeria.

All rights reserved.

Available online at http://www.tjpr.org Original Research Article http://dx.doi.org/10.4314/tjpr.v12i6.6

\title{
Salicornia bigelovii Torr Attenuates Neuro-Inflammatory Responses in Lipopolysaccharide-Induced BV-2 Microglia by Regulation of NF-kappa B Signaling
}

\author{
Hyun Kang ${ }^{1,2}$, Sushruta Koppula ${ }^{1}$ and Tae-Kyu Park ${ }^{1 *}$ \\ ${ }^{1}$ Department of Biotechnology, Research Institute for Biomedical \& Health Science, College of Biomedical and Health Science, \\ Konkuk University, ${ }^{2}$ KuGen Healthcare Institute, Konkuk University Business Incubation Center, Chungju, 380-701, Republic of \\ Korea
}

*For correspondence: Email: taekyupark2@gmail.com; Tel: 82-43-840-3870; Fax: 82-43-852-3616

\begin{abstract}
Purpose: To investigate the anti-oxidant and anti-neuroinflammatory effects of Salicornia bigelovii extract (SBE) in lipopolysaccharide (LPS)-stimulated BV-2 microglial cells.

Methods: Anti-oxidant activity was measured using 1, 1-diphenyl-2-picryl-hydrazyl (DPPH) radical scavenging assay. Cell viability was evaluated using 3-(4, 5-dimethylthiazol-2-yl)-2, 5- diphenyltetrazolium bromide (MTT) assay. BV- microglial cells were stimulated with LPS to study the protein expression and production of inflammatory mediators, determined by Western blot analysis.

Results: SBE significantly inhibited the DPPH-generated free radicals showing maximum inhibition at $40 \mu \mathrm{g} / \mathrm{mL}(p<0.001)$. SBE alone did not exhibit any signs of cytotoxicity to BV-2 cells up to $200 \mu \mathrm{g} / \mathrm{mL}$ concentration. The LPS-induced increase in the production of nitric oxide was concentrationdependently suppressed by SBE ( $p<0.05$ for $10 \mu \mathrm{g} / \mathrm{mL}, p<0.01$ at $20 \mu \mathrm{g} / \mathrm{mL}$ and $p<0.001$ at 40 $\mu \mathrm{g} / \mathrm{mL}$, respectively). SBE also inhibited the LPS-induced increase in inducible nitric oxide synthase (iNOS) and cyclooxygenase-2 (COX-2) expressions. Further, the production of proinflammatory cytokines such as tumor necrosis factor- $\alpha$ and interleukin-6 by LPS-stimulation in BV-2 cells was inhibited by SBE pretreatment. Mechanistic study revealed that SBE acts by regulation of nuclear factor kappa-B signaling pathway in LPS-stimulated BV-2 microglial cells.

Conclusion: This study revealed for the first time that SBE possesses anti-oxidant and antineuroinflammatory effects and can be developed as a potential therapeutic target in ameliorating microglia-mediated neuroinflammation.
\end{abstract}

Keywords: Salicornia bigelovii, Anti-oxidant, lipopolysaccharide; Neuroinflammation, Microglia, Cyclooxygenase, iNOS, NF-KB.

Tropical Journal of Pharmaceutical Research is indexed by Science Citation Index (SciSearch), Scopus, International Pharmaceutical Abstract, Chemical Abstracts, Embase, Index Copernicus, EBSCO, African Index Medicus, JournalSeek, Journal Citation Reports/Science Edition, Directory of Open Access Journals (DOAJ), African Journal Online, Bioline International, Open-J-Gate and Pharmacy Abstracts

\section{INTRODUCTION}

Salicornia bigelovii Torr. (S. bigelovii) commonly known as "Dwarf saltwort" from the family Amaranthaceae, is a leafless annual salt-marsh herb with green jointed and succulent stems [1]. $S$. bigelovii has an exceptional salt tolerance, adaptation to marginal lands and hot climates, therefore has great potential as a domesticated biomass, oilseed, and forage crop plant [2]. $S$. bigelovii has been successfully cultivated as an oilseed and vegetable crop in the desert coastlines of Mexico, India, the Middle East, Africa and in Southeast China [3]. The seed is rich in oil $(30 \%)$ and protein $(35 \%)$ with a high 
content of polyunsaturated linoleic (75\%) and linolenic (omega-3) fatty acids. In addition to its value in human diet, the oil can be used for the production of biodiesel [4]. Earlier studies suggested that Salicornia species has been used as a folk medicine to treat a variety of diseases such as atherosclerosis, hypertension, tumors and claimed as one of the most promising halophytes as immunomodulators [3,5]. However, till date there have been no reports on the antioxidant and anti-neuroinflammatory properties of S. bigelovii.

Microglia, the resident immune cells of the central nervous system, become activated thereby inducing significant and highly detrimental neurotoxic effects by excessively producing a large array of cytotoxic and proinflammatory factors [6]. Microglia-mediated neuroinflammation appears to play an essential role in the pathogenesis of various neurodegenerative diseases such as Alzheimer's disease, Parkinson's disease and multiple sclerosis [7]. Previous reports strongly demonstrated that regulation of microglial activation could reduce neuroinflammation and further neuronal cell damage [8].

Lipopolysaccharide (LPS) is a common toxin used to investigate the impact of inflammation on neuronal death. LPS can directly activate microglia triggering the production of inflammatory mediators, such as nitric oxide (NO), cyclooxygenase (COX)-2, proinflammatory cytokines and leukotrienes [9]. Therefore, LPS-induced inflammatory mediators in vitro can be considered as one of the important tools to evaluate new and existing agents for their anti-neuroinflammatory actions. Recent studies have shown a convincing link between reactive oxygen species (ROS) and neuroinflammation. Inhibition of ROS by several anti-oxidants may suppress microglial activation and thus protect neuronal cell death $[10,11]$. In this study we evaluated the antioxidant potential and anti-neuroinflammatory properties of $S$. bigelovii extract in LPS-stimulated BV-2 microglial cells.

\section{EXPERIMENTAL}

\section{Preparation of S. bigelovii extract}

The dried whole plant of $S$. bigelovii $(5 \mathrm{~kg}$ ) collected during May 2012, were purchased from a local market in South Korea and authenticated by Prof Jong-Bo Kim, a taxonomist at Konkuk University, South Korea. A voucher specimen (SB-KU2012) has been kept in our laboratory herbarium, Konkuk University, South Korea, for future reference. To obtain the $S$. bigelovii extract, the dried plant material was ground in a blender and defatted three times with three volumes of ethanol. The residue was extracted with absolute ethanol at 1:10 ratio $(w / v)$ for $2 \mathrm{~h}$ in a heating mantle at $70-80{ }^{\circ} \mathrm{C}$, and the supernatant was filtered and concentrated in a vacuum evaporator system at $50^{\circ} \mathrm{C}$. For further fractionation, the extract $(1 \mathrm{~kg})$ was partitioned into hexane, chloroform and ethyl acetate fractions to yield $220 \mathrm{mg}, 50 \mathrm{mg}$ and $456 \mathrm{mg}$, respectively. The active ethyl acetate fraction of S. bigelovii extract (SBE, 45.6\%) was lyophilized and stored in a refrigerator $\left(-20{ }^{\circ} \mathrm{C}\right)$ until use. SBE extract was re-dissolved in distilled water and filtered on $0.22 \mu \mathrm{m}$ filters to evaluate its antioxidant and anti-neuroinflammatory activities.

\section{DPPH radical scavenging activity}

The anti-oxidant activity of the SBE was determined using the stable radical 2, 2diphenyl-1-picrylhydrazyl (DPPH, Sigma-Aldrich, St. Louis, MO, USA). The radical scavenging capacity was evaluated by employing a reaction mixture constituted by aliquots of the SBE extract and a DPPH methanolic solution as described previously [12]. Briefly, a sample solution of $60 \mu \mathrm{l}$ of each OFP-EA extract, was added to $60 \mu \mathrm{l}$ of DPPH $(60 \mu \mathrm{M})$ in methanol. After mixing vigorously for $10 \mathrm{~s}$, the mixture was then transferred into a $100 \mu \mathrm{l}$ Teflon capillary tube and the scavenging activity of each sample on DPPH radical was measured using a JES-FA ESR spectrometer (Jeol Ltd., Tokyo, Japan). A spin adduct was measured on an ESR spectrometer exactly after $2 \mathrm{~min}$. Experimental conditions were as follows: central field, 3,475 G; modulation frequency, $100 \mathrm{kHz}$; modulation amplitude, $2 \mathrm{G}$; microwave power, $5 \mathrm{~mW}$; gain, $6.3 \times 10^{5}$, and temperature, $298^{\circ} \mathrm{K}$.

\section{Cell cultures and viability}

BV-2 microglia cells were cultured at $37^{\circ} \mathrm{C}$ in 5 \% CO2 in DMEM (Invitrogen, Carlsbad, CA, USA) supplemented with $5 \%$ foetal bovine serum (FBS, Hyclone, Logan, UT, USA) and 50 $\mu \mathrm{g} / \mathrm{ml}$ penicillin-streptomycin (Invitrogen). In all experiments, cells were pre-treated with the indicated concentrations of SBE for $1 \mathrm{~h}$ before the addition of LPS $(1 \mu \mathrm{g} / \mathrm{ml}$, Sigma-Aldrich, St Louis, MO, USA) in serum free DMEM. An equal volume of sterile water was added to all control treatments. Cell viability was determined by 3-(4, 5- dimethylthiazol-2-yl)-2,5-diphenyltetrazolium bromide (MTT) assay as described previously [13]. Cells were incubated with various concentrations $(0.1,1.0,10,40,60,80,100$ and $200 \mu \mathrm{g} / \mathrm{ml}$ ) of SBE for $24 \mathrm{~h}$ followed by MTT for 4 
$\mathrm{h}$, and then $100 \mu \mathrm{l}$ of isopropanol (in $0.04 \mathrm{~N}$ hydrochloric acid) was added to dissolve the formazan crystals. The absorbance was read at $570 \mathrm{~nm}$ using the Anthos 2010 spectrophotometer (Salzburg, Austria). Cell viability was calculated as relative absorbance compared to control.

\section{Nitric oxide assay}

The amount of stable nitrite, the end product of NO generation, by activated microglia was determined by a colorimetric assay as previously described [14]. Briefly,BV-2 cells $\left(2 \times 10^{5}\right.$ cells $/ \mathrm{ml}$ ) were seeded in 6 -well plates in $500 \mu \mathrm{l}$ complete culture medium and treated with the SBE extract at indicated concentrations $(10,20$ and $40 \mu \mathrm{g} / \mathrm{ml}$ ) for $1 \mathrm{~h}$ prior stimulation with LPS $(1 \mu \mathrm{g} / \mathrm{ml})$ for $2 \mathrm{~h}$. $50 \mu \mathrm{l}$ of culture supernatant was mixed with an equal volume of Griess reagent and incubated at room temperature for $10 \mathrm{~min}$. The absorbance at $540 \mathrm{~nm}$ was read using a PowerWavex Microplate Scanning spectrophotometer (Bio-Tek Instrument, Winooski, VT, USA). Nitrite concentration was determined by extrapolation from a sodium nitrite standard curve.

\section{Nuclear protein extraction and Western blot analysis}

Cells were washed in cold PBS three times and lysed in a buffer containing $50 \mathrm{mM}$ Tris- $\mathrm{HCl}, \mathrm{pH}$ $7.4,1 \%(\mathrm{v} / \mathrm{v})$ Tergitol- type NP-40 (NP-40), 0.25 $\%$ sodium deoxycholate, $150 \mathrm{mM} \mathrm{NaCl}, 1 \mathrm{mM}$ EDTA, $25 \mathrm{mM} \mathrm{NaF}, 2 \mathrm{mM}$ Sodium orthovanadate (Na3VO4) and protease inhibitor cocktail (Complete MiniTM, Roche, Mannheim, Germany) at $4{ }^{\circ} \mathrm{C}$. The lysate was clarified by centrifugation at $10,000 \mathrm{~g}$ for $20 \mathrm{~min}$ at $4{ }^{\circ} \mathrm{C}$ to remove insoluble components. Cell lysates were normalized for protein content using bicinchoninic acid (BCA) reagent (Pierce, Rockford, IL, USA). Equal amounts of protein were loaded onto $10 \%$ poly acryl amide gel electrophoresis (PAGE) and separated by standard sodium dodecyl sulphate (SDS)-PAGE procedure. Proteins were transferred to an NC membrane (S\&S, Dassel, Germany) and blocked with $5 \%$ non-fat dry milk in TBS. To detect protein expression, the blots were probed with specific antibodies for iNOS (1:1000), COX-1 (1:1000), COX-2 (1:1000), NF-kB, I $\quad$ B- $\alpha$ (1:1000), anti-p-IKB- $\alpha$ and $\beta$-actin $(1: 2000)$ followed by a $1 \mathrm{~h}$ incubation with horseradish peroxidase-conjugated secondary antibodies $(1: 1000-2000)$ (Bio-Rad, Herculus, CA, USA) with $\beta$-actin as internal control. The immunoreactive proteins on the membrane were detected by chemiluminescence using the West-
Save substrate (Lab-Frontier, Seoul, Korea) on $X$-ray film. The antibodies against inducible nitric oxide synthase (iNOS), cyclooxygenase (COX) 1, COX-2, nuclear factor kappa-B (NF-KB), I kappa B-alpha (IKB- $\alpha$ ) and $\beta$-actin were purchased from Cell Signaling Technology Inc (Beverly, MA, USA).

\section{IL-6 assay}

BV-2 microglia cells $\left(1 \times 10^{5}\right.$ cells/well $)$ were cultured on 96-well plates and treated with SBE at indicated concentrations with or without LPS $(1 \mu \mathrm{g} / \mathrm{ml})$. At $4 \mathrm{~h}$ of post LPS treatment, the cells were collected and the supernatants were subjected to assay of IL-6 contents using a murine IL-6 ELISA kit from BD Biosciences (San Jose, CA, USA) according to the manufacturer's instruction.

\section{TNF- $\alpha$ assay}

BV-2 microglia cells $\left(1 \times 10^{5}\right.$ cells/well $)$ were cultured on 96-well plates and treated with the SBE at indicated concentrations for $1 \mathrm{~h}$ and stimulated with LPS $(1 \mu \mathrm{g} / \mathrm{ml})$. At $4 \mathrm{~h}$ post-LPS treatment, the cells were collected and the supernatants were evaluated for TNF- $\alpha$ level using a murine TNF- $\alpha$ ELISA kit from BD Biosciences (San Jose, CA, USA) according to the manufacturer's instructions.

\section{Statistical analysis}

All data are represented as the mean \pm SEM of at least three independent experiments. Statistical analyses were performed using SAS statistical software (SAS Institute, Cray, NC, USA) using one-way analysis of variance, followed by Dunnett's multiple range tests.

$<0.05$ was considered statistically significant.

\section{RESULTS}

\section{Effect of SBE extract on DPPH radical scavenging activity}

As shown in Fig $1 \mathrm{~A}$, SBE exhibited significant DPPH radical scavenging activity in a concentration-dependent manner showing a maximum effect at $40 \mu \mathrm{g} / \mathrm{ml}$ of concentration ( $p$ $<$ 0.001). The ESR spectroscopy data is represented in Fig 1B.

\section{Effect of SBE on BV-2 microglial cell viability}

As shown in Fig. 2, SBE treatment for $24 \mathrm{hr}$ at various concentrations ranging from $0.1 \mu \mathrm{g} / \mathrm{ml}$ to $200 \mu \mathrm{g} / \mathrm{ml}$ did not exhibit any significant cytotoxicity on BV-2 microglial cells. 

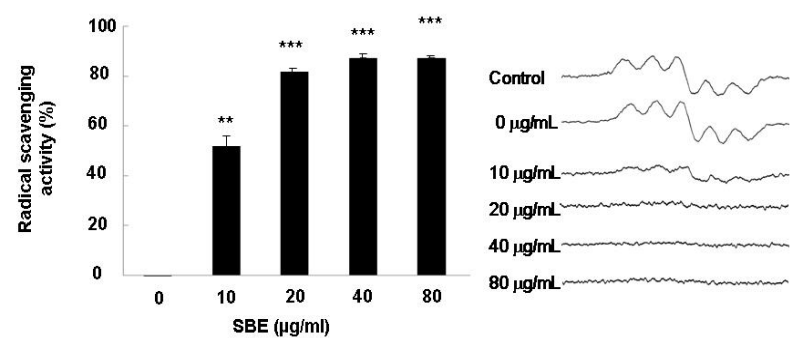

Fig 1: Effect of SBE on DPPH radical scavenging activity. The capacity to scavenge DPPH free radical by different concentrations of SBE (A) and ESR spectra (B) was measured. BV-2 cells were treated with or without SBE at the various concentrations (10, 20,40 and $80 \mu \mathrm{g} / \mathrm{ml}$ ). The scavenging activity of each sample on DPPH radical was measured using a JESFA ESR spectrometer. A spin adduct was measured on an ESR spectrometer exactly 2 min later. Data are presented as the mean \pm SEM $(n=3) ;{ }^{* *} p<0.01$ and ${ }_{* * *} p<0.001$, compared with control group by one-way analysis of variance, followed by Dunnett's multiple range tests. SBE $=$ Salicornia bigelovii extract.

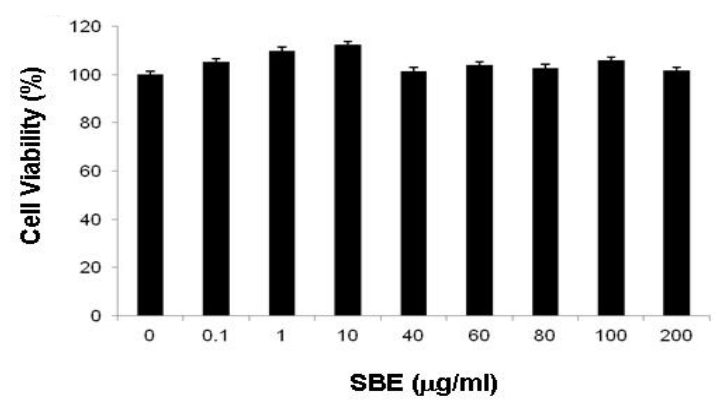

Fig. 2: Effect of SBE on the viability of BV- 2 microglial cells. Viability in-SBE treated cells was determined using MTT assay. The results are depicted as percentage of control samples. Data are presented as the mean \pm SEM $(n=3)$. SBE = Salicornia bigelovii extract.

\section{Effect of SBE on LPS-induced NO production in BV-2 microglial cells}

As shown in Fig 3 , cells treated with LPS alone significantly increased the NO levels $(p<0.001)$. Pretreatment with SBE $(10,20,40$ and $80 \mu \mathrm{g} / \mathrm{ml})$ significantly suppressed the LPS-stimulated increased NO release in BV-2 cells in a dosedependent manner compared to LPS only treated cells. The maximum effect was observed at a concentration of $100 \mu \mathrm{g} / \mathrm{ml}(p<0.001)$.

\section{Effect of SBE on LPS-induced expression of iNOS and COX levels in BV-2 microglial cells}

SBE exhibited a broad spectrum of inhibitory effect on the expression of pro-inflammatory mediators and reduced the LPS-stimulated increase of protein expression such as iNOS and inducible COX-2 in a concentration-dependent manner. However, constitutive COX-1 protein expressional levels were uninterrupted (Fig 4).

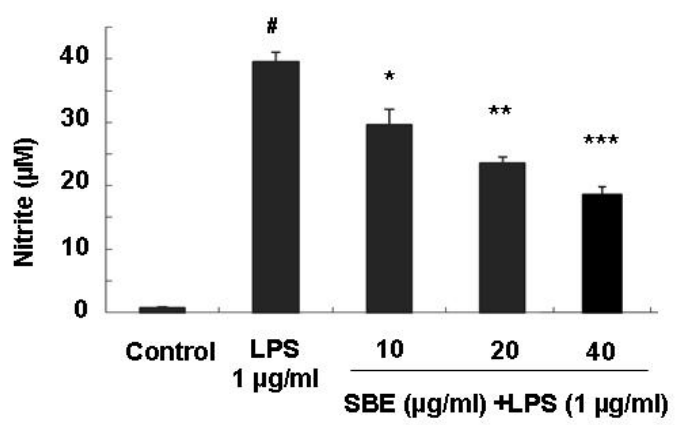

Fig 3: Effect of SBE on NO Production in LPSstimulated BV-2 microglial cells. BV-2 cells were treated with SBE at indicated concentrations $(10,20$ and $40 \mu \mathrm{g} / \mathrm{ml})$ with or without LPS $(1 \mu \mathrm{g} / \mathrm{ml})$ for $4 \mathrm{~h}$. The nitrite in the culture supernatant was evaluated using Griess reagent. Data are presented as the mean \pm S.E.M. $(\mathrm{n}=3) ;{ }^{\#} p<0.001$, when compared with control group. ${ }^{*} p<0.05,{ }^{* *} p<0.01$ and ${ }^{* * *} p<0.001$, when compared with LPS alone treated group by oneway analysis of variance, followed by Dunnett's multiple range tests. $\mathrm{SBE}=$ Salicornia bigelovii extract.

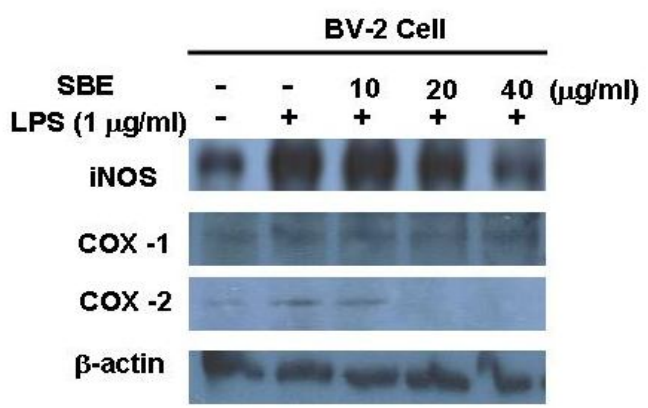

Fig 4: Effect of SBE on iNOS, COX-1 and COX-2 protein expressional levels in LPS-stimulated BV-2 microglial cells. The expression levels of iNOS, COX-1 and COX-2 production in the LPS-stimulated BV-2 cells by various concentrations $(10,20$ and $40 \mu \mathrm{g} / \mathrm{ml})$ of the SBE was monitored by immunoblot analyses with the specific antibodies against iNOS, COX-1 and COX-2. The internal control used was $\beta$-actin. SBE = Salicornia bigelovii extract.

\section{Effect of SBE on TNF- $\alpha$ and IL- 6 production in LPS-stimulated BV-2 microglial cells}

As shown in Fig 5, TNF- $\alpha$ level increased significantly after LPS treatment when compared to those in untreated cells $(p<0.001)$. However, SBE significantly inhibited TNF- $\alpha$ production in a concentration dependent manner $(p<0.01$ at 10 $\mu \mathrm{g} / \mathrm{ml}$ and $p<0.01$ at 20 and $p<0.001$ at 40 $\mu \mathrm{g} / \mathrm{ml}$, respectively). LPS stimulation increased the IL-6 expression in BV- cells. However, pretreatment with SBE at various concentrations significantly and dose dependently decreased $(p$ $<0.05$ at $10 \mu \mathrm{g} / \mathrm{ml}, \mathrm{p}<0.01$ at $20 \mu \mathrm{g} / \mathrm{ml}$ and $\mathrm{p}<$ 
0.001 at $40 \mu \mathrm{g} / \mathrm{ml}$ ) the LPS-induced IL-6 levels in BV-2 microglia (Fig 6).

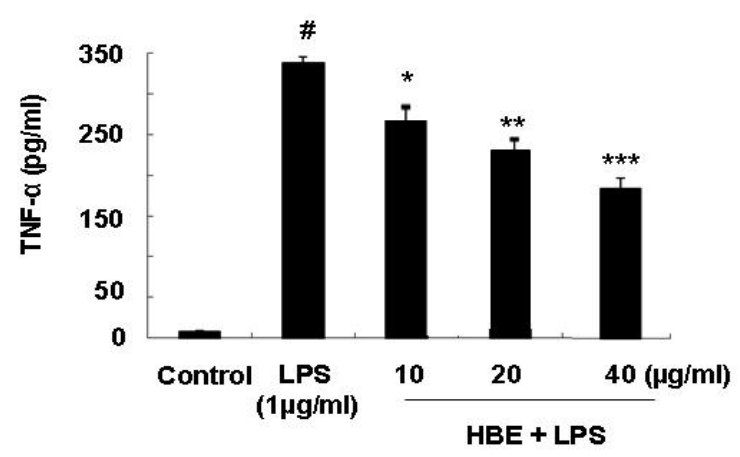

Fig 5: Effect of SBE on pro-inflammatory cytokine TNF-a level in LPS-stimulated BV-2 cells. BV-2 cells were treated with SBE at indicated concentrations (10, 20 and $40 \mu \mathrm{g} / \mathrm{ml})$ with or without LPS $(1 \mu \mathrm{g} / \mathrm{ml})$ for $4 \mathrm{~h}$. The TNF- $\alpha$ level in the culture supernatant was evaluated using a specific ELISA kit from BD Sciences according to the manufacturer's instruction. Data are presented as the mean \pm S.E.M. $(\mathrm{n}=3)$. ${ }^{\sharp} p<0.001$, compared with control group. ${ }^{*} p<0.05,{ }^{* *} p<0.01$, ${ }^{* * *} p<0.001$, compared with LPS alone treated group by one-way analysis of variance, followed by Dunnett's multiple range tests. SBE = Salicornia bigelovii extract.

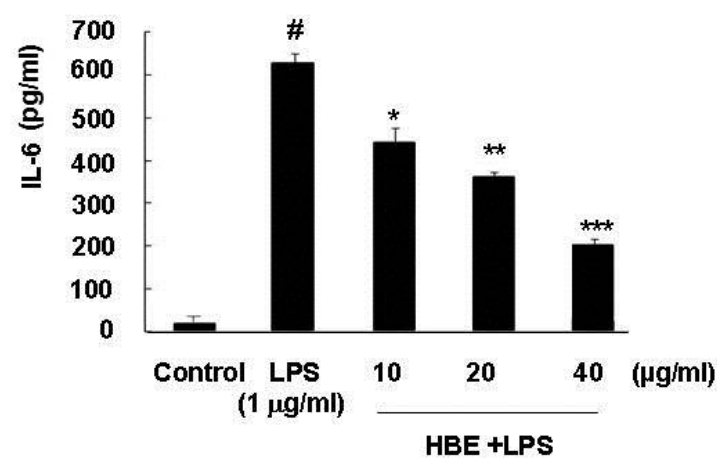

Fig 6: Effect of SBE on pro-inflammatory cytokine IL-6 expression in LPS-stimulated BV-2 cells. BV-2 cells were treated with SBE at indicated concentrations (10, 20 and $40 \mu \mathrm{g} / \mathrm{ml}$ ) with or without LPS $(1 \mu \mathrm{g} / \mathrm{ml})$ for 4 $\mathrm{hr}$. The IL- 6 in the culture supernatant was evaluated using a murine IL-6 ELISA kit from BD Sciences according to the manufacturer's instruction. Data are presented as the mean \pm SEM $(n=3)$. ${ }^{*} p<0.001$, when compared with control group. ${ }^{*} p<0.05$, ${ }^{* *} p<$ $0.01,{ }^{* * *} p<0.001$, compared with LPS alone treated group by one-way analysis of variance, followed by Dunnett's multiple range tests. SBE = Salicornia bigelovii extract.

\section{Effect of SBE on NF-KB in LPS-stimulated BV-2 microglial cells}

SBE inhibited the LPS-induced phosphorylation and degradation of IKB- $\alpha$, and nuclear translocation of $\mathrm{p} 65 \mathrm{NF}-\mathrm{KB}$ in a concentration dependent manner (Fig 7).

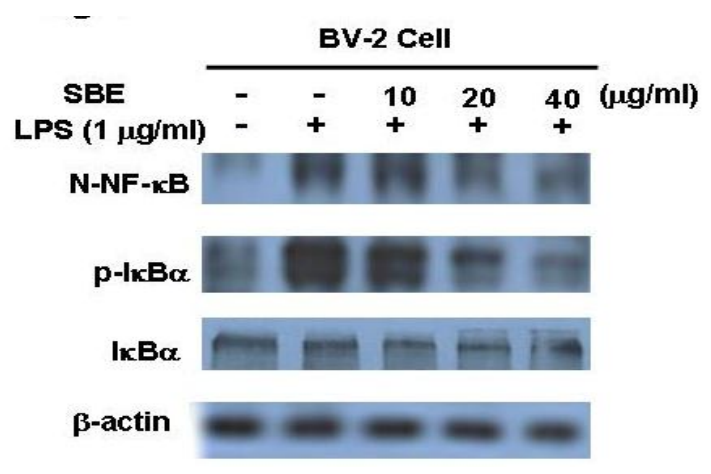

Fig 7: Effect of SBE on NF-KB activity in LPSstimulated BV2 microglia. The expression levels of IKB- $\alpha$, and nuclear translocation of p65 NF-KB in the LPS-stimulated BV-2 cells by indicated concentrations $(10,20$ and $40 \mu \mathrm{g} / \mathrm{ml})$ of the SBE was monitored by immunoblot analyses with the specific antibodies. The internal control used was $\beta$-actin. Data are presented as the mean \pm SEM $(n=3)$ for three independent experiments. SBE = Salicornia bigelovii extract.

\section{DISCUSSION}

In the present study, proinflammatory stimulus by LPS to BV-2 cells resulted in excessive production of NO. Earlier studies revealed that prolonged activation of microglial cells leads to increased release of NO by iNOS in the brain. $\mathrm{NO}$, an important regulatory mediator involved in cell survival and death exerts a number of proinflammatory effects during several physiological and pathological processes leading to increased inflammatory reaction. It was well known that COX-1 is constitutively expressed in many cell types and COX-2 is normally not present in most cells, but its expression is induced in response to inflammatory cytokines linked to pathological events [15]. COX-2 is upregulated in response to various inflammatory stimuli including LPS in BV2 microglia. Therefore, agents that inhibit the release of NO and attenuate iNOS and COX-2 expression could be beneficial for preventing and delaying the progression of neuroinflammatory disease. [16]. Data from our study clearly showed that SBE attenuated LPS-induced iNOS and COX-2 expression and downstream NO production. However, SBE has no influence on the constitutive COX-1 expression.

Pro-inflammatory cytokines such as TNF- $\alpha$, IL$1 \beta$, and IL- 6 play central roles in microgliamediated inflammation [17]. In particular, increased levels of brain TNF- $\alpha$ and IL- 6 has been associated with severe cognitive impairments, neuronal damage and neuroinflammation [17]. Therefore, the effects of SBE on proinflammatory cytokine TNF- $\alpha$ and IL6 production in LPS-stimulated BV-2 microglial cells were evaluated. LPS-stimulation increased the levels of TNF- $\alpha$ and IL-6 in BV-2 cells. 
However, pretreatment with SBE suppressed the increased TNF- $\alpha$ and IL- 6 production indicating that SBE may convincingly be an effective antineuroinflammatory agent.

NF-kB, a mammalian transcription factor, activated by LPS, is known to control the expression of cell survival genes as well as proinflammatory enzymes and cytokines [18]. Our result showed that SBE inhibited the LPSinduced phosphorylation/degradation of IKB- $\alpha$ and translocation of NF-kB/p65 sub unit in a concentration-dependent manner. Considering the above data, we can conclude that NF-kB is a major target of SBE. However, the exact molecular target of SBE on NF-KB activation remains to be elucidated.

The mechanism of neuro-inflammation is partly attributed, to release of toxic free radicals and ROS from activated microglia which may participate in the neurodegenerative process. $\mathrm{DPPH}$ radical assay is one of the widely used methods for screening the free radical scavenging activities of several agents in a relatively short period of time. In the present study, SBE significantly scavenged the DPPH free radicals. Reports from earlier studies indicated that $S$. bigelovii posses active constituents such as triterpenoids, flavones, glycosides, saponins, vitamins and minerals $[3,19]$. Salicornia species were also reported to posses' strong anti-oxidant properties [20,21]. In light of such reports, the strong anti-oxidant activity exhibited by SBE supports the notion that SBE might play a promising role in exhibiting anti-neuroinflammatory properties in LPSstimulated BV-2 cells.

\section{CONCLUSION}

This study revealed for the first time that SBE inhibits neuro-inflammatory responses via NF-KB signaling in LPS-stimulated BV-2 microglial cells. Further, the antioxidant potential of SBE might partly be involved for the observed effects.

\section{CONFLICT OF INTEREST}

The authors declare that no conflict of interest exists regarding this work.

\section{ACKNOWLEDGEMENT}

This work was supported by Konkuk University in the year (2013). The author's Kang $H$ and Koppula S contributed equallyto this work.

\section{REFERENCES}

1. Edward PG, Oleary JW, Watson MC, Thompson $T L$, Kuehl RO. An oil seed halophyte for seawater irrigation. Science 1991; 251 (4997), 1065-1067.

2. Masters DG, Benes SE, Norman HC. Biosaline agriculture for forage and livestock production. Agr Ecosyst Environ 2007; 119: 234-248.

3. Lu D, Zhang M, Wang S, Cai J, Zhou X, Zhu C. Nutritional characterization and changes in quality of Salicornia bigelovii Torr. during storage. LWT Food Sci Tech 2010; 43: 519-524.

4. Anwar F, Bhanger M I, Nasir MKA, Ismail S. Analytical characterization of Salicornia bigelovii seed oil cultivated in Pakistan. J Agri Food Chem 2002; 50 (15): 4210-4214.

5. Im SA, Kim KJ, Lee CK. Immunomodulatory activity of polysaccharides isolated from Salicornia herbacea. Int Immunopharmacol 2006; 6(9): 1451-1458.

6. Block ML, Hong JS. Microglia and inflammation-mediated neurodegeneration: multiple triggers with a common mechanism. Prog Neurobiol, 2005; 76: 77-98.

7. Perry VH, Gordon S. Macrophages and microglia in the nervous system. Trends Neurosci 1988; 11: 273277.

8. Liu B, Hong J.S. Role of microglia in inflammationmediated neurodegenerative diseases: mechanisms and strategies for therapeutic intervention. J Pharmacol Exp Ther 2003; 304: 1-7.

9. Xie QW, Kashiwabara Y, Nathan C. Role of transcription factor NF-kappa B/Rel in induction of nitric oxide synthase J Biol Chem 1994; 269 (7): 4705-4708.

10. Agullo G, Gamet-Payrastre L, Manenti S, Viala C Rémésy $\mathrm{C}$, Chap $\mathrm{H}$, et al. Relationship between flavonoid structure and inhibition of phosphatidylinositol 3-kinase: a comparison with tyrosine kinase and protein kinase C inhibition. Biochem Pharmacol 1997; 53:2087-2094.

11. Araki E, Forster C, Dubinsky JM, Ross ME, ladecola C. Cyclooxygenase-2 inhibitor NS-398 protects neuronal cultures from lipopolysaccharide-induced neurotoxicity. Stroke 2001; 32: 2370-2375.

12. Sanches-Moreno $C$, Plaza $L$, Ancos B, Cano MP Nutritional characterization of commercial trnaditional pasteurized tomato juices: carotenoids, vitamin and radical-scavenging activity. Food Chem 2006; 98: 749-756.

13. Reis K, Halldin J, Fernaeus S, Pettersson C, and Land T. $N A D P H$ oxidase inhibitor diphenyliodonium abolishes lipopolysaccharide induced down regulation of transferrin receptor expressions in N2a and BV-2 cell. J Neurosci Res 2006; 84:10471052.

14. Green LC, Wagner DA, Glogowski J, Skipper PL, Wishnok JS, Tannenbaum SR. Analysis of nitrate, nitrite, and $\left[{ }^{15} \mathrm{~N}\right]$ nitrite in biological fluids. Anal Biochem 1982; 126: 131-138.

15. Teismann $P$, Vila M, Choi DK, Tieu K, Wu DC, JacksonLewis V, Przedborski S. COX-2 and neurodegeneration in Parkinson's disease. Ann. N.Y. Acad. Sci 2003; 991: 272 - 277.

16. Boucher JL, Moali C, Tenu JP. Nitric oxide biosynthesis, nitric oxide synthase inhibitors and arginase competition for L-arginine utilization. Cell Mol Life Sci 1999; 55:1015-1028.

17. Hunot S, Hartmann A, Hirsh EC. The inflammatory response in the Parkinson brain. Clin Neurosci Res 2001; 1: 434-443.

18. Baldwin AS Jr. The NF-kappa B and I kappa B proteins: new discoveries and insights. Annu Rev Immunol 1996; 14: 649-683.

19. Xia GP, Feng $X$, Chen $Y$, Wang, M, Dong YF. Chemical constituents of Salicornia bigelovii Torr. Natural 
Product Research and Development , 2010; 22(6): 1012-1014.

20. Daffodil ED, Rajalakshmi K, Mohan VR. Antioxidant avtivity, total phenolics and flavonoids of Salicornia brachiata Rox. Leaf extracts (Chenopodiaceae). World J Pharm Pharm Sci 2013; 2(1): 352-366.
21. Kim YA, Kong CS, Um YR, Lim SY, Yea SS, Seo Y. Evaluation of Salicornia herbacea as a potential antioxidant and anti-inflammatory agent.J. Med. Food. 2009; 12:3; 661-668. 